\title{
Article \\ Political Participation of Young Voters: Tracing Direct and Indirect Effects of Social Media and Political Orientations
}

\author{
Rehan Tariq, Izzal Asnira Zolkepli *(D) and Mahyuddin Ahmad
}

check for updates

Citation: Tariq, Rehan, Izzal Asnira Zolkepli, and Mahyuddin Ahmad. 2022. Political Participation of Young Voters: Tracing Direct and Indirect Effects of Social Media and Political Orientations. Social Sciences 11: 81. https://doi.org/10.3390/ socsci11020081

Academic Editor: Daniel Stockemer

Received: 24 December 2021

Accepted: 11 February 2022

Published: 17 February 2022

Publisher's Note: MDPI stays neutral with regard to jurisdictional claims in published maps and institutional affiliations.

Copyright: (C) 2022 by the authors. Licensee MDPI, Basel, Switzerland. This article is an open access article distributed under the terms and conditions of the Creative Commons Attribution (CC BY) license (https:// creativecommons.org/licenses/by/ $4.0 /)$.
School of Communication, Universiti Sains Malaysia, Penang 11800, Pulau Pinang, Malaysia; rehantariq@student.usm.my (R.T.); din_rahman@usm.my (M.A.)

* Correspondence: izzalasnira@usm.my

\begin{abstract}
Political participation in Pakistan was expected to rise because of the enormous democratic potential of social media; nevertheless, a drop has been observed following an initial increase. This scenario encourages investigation of the decisive factors that might draw disengaged citizens into participatory politics. Therefore, this study illustrates the results of a Pakistani sample $(n=410)$ regarding the role of social media in influencing political participation in online and offline platforms. Five variables were examined using partial least squares (PLS) to see how they influenced online and offline political participation. The OSOR model of communication mediation was used for this purpose. Its implications were extended by simultaneously incorporating three outcome orientations-political expression, political efficacy, and partisanship-as mediators. In addition, we included political interest as an antecedent orientation and social media use as stimuli. Online and offline political participation were placed under response as endogenous variables. Our findings acknowledged nine direct and five indirect correlations out of ten direct and six indirect relationships. Political efficacy neither influenced offline political participation nor proved to be a mediator between social media use and offline political participation. We conclude with study implications, limitations, and recommendations for future scholars.
\end{abstract}

Keywords: OSOR model; partisanship; political efficacy; political expression; political interest; political participation; social media use

\section{Introduction}

In political communication, the influential role of modern communication technology in developing democratic strength, the formation of political attitudes and political participation have become matters of great concern for scholars (Galandini and Fieldhouse 2019; Széll 2018). The development of internet structure, and the introduction of social media, have further sparked scholarly interest in the study of political behaviours on social media platforms (Lipschultz 2015). Modern philosophers and sociologists emphasize on the moral demand of active, responsible, and informed citizenship in contemporary democratic politics. According to Grechyna (2020) the increasing tendency of political disengagement among citizens is accentuated as political stagnation in the pool of the democratic system. In democratic deliberations, a participatory public has long been regarded as a critical component of politics and the strength of the political system. A well-informed and politically active electorate, in a democratic system, is the most important constraint on the negligence and malpractices of the elected governments. This notion expressed by social scientists has confirmed that political participation is at the centre of a democratic political formula. Democracy will lack credibility and guiding power if the public is not involved in the political process (Guven 2020).

Meanwhile, concerns regarding the political involvement of youth have sparked researchers' interest, resulting in a surge of studies from a metatheoretical and crossdisciplinary perspective (Mustapha and Omar 2020). Therefore, exploring the decisive 
factors that can bring distanced citizens back to participatory politics has turned into a cornerstone in present day political communication research (Kim and Hoewe 2020). A substantial number of studies have established a significant strong association between social media use and engagement in political activities (see Halpern et al. 2017; Yamamoto et al. 2020). Similar perceptions about the democratic power of a politically active public exist among scholars of less developed democracies such as Pakistan (Mangi et al. 2019), where a considerable segment of youth is engaged in political activities through social media (Ahmad and Sheikh 2013).

However, instead of the increasing trend of new digital horizons, particularly social media, the problem of political disengagement has surfaced again in Pakistan. Despite the rise in social media use in Pakistan, voter turnout declined in the most recent general elections, held in 2018 (Election Commission of Pakistan 2018). This brought major concerns about the democratic future of a country that is already struggling to regain democratic strength (Ida et al. 2020). Therefore, in this study, we crystalized and catalogued new links affecting political participation in Pakistan within the OSOR communication mediation model.

\section{Literature Review}

This section demonstrates the dissatisfaction of young people with democracy; the emergence of social networks; the role of social media in defining the political orientation of young voters in Pakistan; a thorough discussion of theoretical underpinnings; and the development of a conceptual framework, by connecting hypothetical relationships based on previous literature.

\subsection{Young People's Dissatisfaction with Democracy}

Throughout history, young people have undoubtedly been a creative force in revolutionary movements launched for the socio-economic and political rights of the people (Schmalzer 2015). In recent years, it has been observed that the younger generation is more dissatisfied with democratic performance than the older generation. Numerous factors have contributed to this dissatisfaction. In the developed democracies of the Global North, there is a growing disparity in life opportunities across generations (Grasso and Giugni 2022). Without inherited money, it has become difficult for young people to find work, buy a home, have a family, or advance in life. As a result, they frequently express dissatisfaction with democracy. Meanwhile, developing democracies in the Global South are grappling with corruption, poor governance, and an absence of the rule of law. The younger generation in these countries has grown up with the shortcomings of the democratic system, in contrast with the time of "democratic struggle" experienced by their elders. As a result, dissatisfaction with the democratic system is widespread among the younger generations in these countries (Foa et al. 2020).

The emergence of social media on the political spectrum provided a ray of hope. It has been noted that youngsters are eager to participate in politics if it entails face painting, witty banners, scandalous yelling, and posting it on social media with a trending hashtag. Popular social-media-based campaigns, such as Black Lives Matter and anti-Brexit marches in the United Kingdom, have proved extremely effective in mobilizing young people (Brändle et al. 2022). Although these movements were effective in mobilizing youth, whether they resulted in the intended change is questionable. There is evidence that young people's participation in governance and formal institutional reforms is quite low (Fakih et al. 2020). This is the reason that, in the age of social media, young people can actively launch a political campaign, but owing to a lack of representation in policymaking institutions, they are unable to achieve actual change. This is a depressing situation for youth, which may lead to an increase in skepticism and a decrease in participation (Campbell 2020). 


\subsection{The Emergence and Impact of Social Networks}

In the contemporary world, rapid, modern, and interactive communication technology have proposed new patterns of deliberations. By introducing the "Web", Tim BurnersLee modernized the communication world. The first generation of the World Wide Web, technically known as Web 1.0, was read-only and had less space for user contribution. Dale Dougherty addressed the limitations of Web 1.0 by introducing Web 2.0 (Khanzode and Sarode 2016). Further development of the web paradigm in terms of Web 3.0 and Web 4.0 merged human and artificial intelligence and improved online searching; it promoted the concept of social networking, expedited the flow of information, and facilitated usergenerated content (Almeida 2017).

Social networking through social media has enabled people to broadcast information, obtain feedback on that information, observe information broadcast by others, provide feedback on their posts, and engage in social comparison. Subsequently, the global usage rate of the popular social media apps, Facebook, YouTube, WhatsApp, Instagram, WeChat, and TikTok jumped to billions (Statista 2021). Although initial discussions about social media platforms were made in the context of business and marketing convenience, these platforms eventually facilitated almost all segments of society. The consistent cognitive process through social media engagement fulfils the essential criteria of deliberative democracy (Halpern and Gibbs 2013). It has been widely employed for political purposes during the past decade. Even TikTok, a popular social media platform known for its entertaining videos, is increasingly becoming a forum for political debates and political activities (Cervi and Marín-Lladó 2021). Thus, a rigorous analysis is required to examine the impact of social media on political participation in a modern democracy.

\subsection{Social Media and Political Orientations of Youth in Pakistan}

The sharp rise in the adoption of information and communication technology (ICT) has made it relatively easy for the people of Pakistan to acquire information through interactive forms of social media (Michaelsen 2011). Social media platforms have become effective and influential communication tools in Pakistani politics, and their popularity is growing, especially among youth. As the use of social media grows among young people in Pakistan, they become more politically active and more likely to become involved in traditional forms of politics (Ahmad et al. 2019). In fact, before the general election 2013 there were 30 million Internet users in Pakistan, out of which 13 million were social media users (Ali et al. 2013). Conversely, before the general elections of 2018, there were 44.6 million Internet users in Pakistan (Statista 2018), out of which 35 million were active social media users (Alphapro 2018). The political worth of social media has been proved in Gallup Pakistan's (2018) survey, which reports that $48 \%$ of the Pakistanis use the Internet, at least once in a day, to obtain news from social media. These statistics indicate that a sizeable segment of youth, which is also a major proportion of population, have become engaged in political activities via social media. The research in this area is still at the exploratory stage, particularly in developing countries of South Asia such as Pakistan (Mahmood et al. 2020). Due to its democratic disposition, it is essential to examine the significance of social media in designing the political orientation of youth in the distinctive political circumstances of Pakistan.

The majority of research regarding social media input most often begins with social media use (Lee and Xenos 2019). This is why such studies fail to foresee the hidden reasons for behavior changes during social media use that may be driven by distinguished political backgrounds, such as political interest and partisanship (Lu and Lee 2021). Therefore, political interest has been included in this study as a background orientation for social media use, and partisanship as an outcome orientation of social media use, while keeping a typical Pakistani political background, where partisanship is a major factor in determining people's political activities (Shahzad and Omar 2021). A recent study by Ohme (2021) has also highlighted the importance of partisanship while discussing the exposure and dissemination of political content on social media platforms. 
Social media politically mobilizes citizens in cyberspace, where restrictions over political expression are difficult to impose by governments. This creates a new space for political expression (Lane 2020) and online political participation (Joseph 2011). Importantly, the significance of political expression is meaningful in a country such as Pakistan where, recently, the indirect involvement of the military in the political process, and the intimidation of journalists and media houses to manipulate the political horizon and election results, were massively reported (Tharoor 2018). In such congestive political circumstances, the existence of social media is a blessing for citizens. It is noted that the presence of youth on social media has prompted the culture of political expression, developed political efficacy and created new forms of sociability (Chen and Chan 2017).

Recently, as an outcome of this sociability, several revolutionary movements such as the Arab Spring, the Green Movement in Iran, the \#FeesMustFall movement in South Africa, and the \#ThisFlag movement in Zimbabwe, demonstrated social-media-based political activism (Patrut and Patrut 2014; Musarurwa 2016; Langa 2017). Although social media penetration did not result in extended violent revolutionary upheavals in Pakistan, it had a considerable impact on the country's political dynamics. Practically, social media's impact on Pakistan's democratic dynamics was witnessed for the first time in the general elections of 2013 (Ahmed and Skoric 2014). As compared to the Election Commission of Pakistan (2013), National Assembly turnout increased to $55 \%$, whereas in 2008, the general election turnout was $44 \%$. The general elections of 2018 in Pakistan witnessed more intensive political campaigns over social media. The political parties used social media as a political weapon against each other, although, according to a report by the Election Commission of Pakistan (2018), there was a 3.4\% decline in turnout.

Because of the above scenario, it is significant to investigate Pakistan-where a large fraction of the population, especially young people, have become addicted to social media (Ida et al. 2020) — as an example, to find out social media's role in political participation. Overall, we are concerned with testing the political connotations of social media and elaborating a comprehensive process that works to connect motivation for social media use to political participation among the youth of Pakistan. The OSOR model has provided a theoretical lens to investigate new links between the social media use, political orientation, and political behaviour of Pakistani youth.

\subsection{OSOR Model of Communication Mediation}

The notion of studying communication as a process to measure participation level is not new. As far as political participation is concerned, it is influenced by various psychological and structural factors, which have a significant influence on behavioural outcomes. These factors are comprehensively combined in communication mediation models. Researchers often adopt communication mediation as a framework to interpret the relationship between information consumption, cognitive process, and political engagement (Lee 2017). We also grounded our research in a communication mediation model, known as the OSOR (orientation-stimuli-orientation-response) model. The OSOR model illustrates communication as a process in which cognitive variables, with media interaction, lead to political outcomes McLeod et al. (2002).

\subsubsection{Antecedent Orientation: First " $\mathrm{O}$ "}

The first " $\mathrm{O}$ " represents "the set of structural, cultural, cognitive and motivational characteristics the audience brings to reception situation that affect the impact of messages" (McLeod et al. 2009). However, it is well-mentioned in previous studies that research based on communication mediation has yet to consider the role of the motivations for social media use (Chen and Chan 2017). Therefore, the current study addressed this issue by using political interest as the motivation for social media use. Although it is generally explored that social media is used for entertainment and staying connected with others (Boyd 2008), scholars in social media research anticipate that individuals' intentions for social media use vary (Baumgartner and Morris 2010). 
Currently, social media is widely used by young adults to gratify their political needs. Studies have found that the use of social media among US adults for news updates increased from 43\% to 67\% (Thompson et al. 2020). Previous studies (see Min 2010; Bakker and Vreese 2011; Holt et al. 2013) have consistently depicted that political interest as a motivation is powerful predictor of news consumption, political learning and political participation. While illustrating the mediation process, Tian (2011) revealed the importance of political interest as an antecedent-orientation variable and predictor of media exposure. Based on the presented literature, this study placed political interest under the first " $\mathrm{O}$ " in the OSOR framework. In Pakistan, where political orientation is strong and social media usage for political reasons has risen in recent years, it would be interesting to investigate the influence of political interest as an antecedent orientation on social media use. Therefore, we hypothesised:

Hypothesis 1 (H1). Political interest positively influences the use of social media among young voters.

\subsubsection{Stimuli: " $\mathrm{S}$ "}

The "S" stands for stimuli, and it represents media messages. It also deals with the initial selective control of individuals' mental activity in deciding what stimuli they have to attend to and what stimuli they have to ignore (Lee 2017). Research related to political communication effects specifies ample evidence that media effects are conditional, and depend on orientation and exposure to media content stimuli (McLeod et al. 2009). Reichert and Print (2017) conducted an analysis that concluded that exposure to political content in the media stimulates political discussions, which further improves cognizance about political affairs and confidence to engage in political activities. Previous studies (see Hoffman and Thomson 2009; Chen and Chan 2017) have also recognized media use as a stimulus for political engagement. More importantly, the growing trend of using social media as a source of information, current affairs, and sharing user-generated content has been observed, particularly among younger people (Kushin and Yamamoto 2010). Therefore, based on the presented literature, this study considered social media use as a stimulus for further political engagements.

The nature of social media sites introduces an advanced form of media where people can engage in politics by expressing their political views (Velasquez and Rojas 2017). Presence on social media significantly enhances the level of political efficacy (Hwang 2020) and the strength of partisan (Iftikhar et al. 2021) among users. That is why we predicted a positive influence of social media use on political efficacy, political expression, and partisanship.

Hypothesis 2 (H2). Social media use positively influences the level of political efficacy among young voters.

Hypothesis 3 (H3). Social media use positively influences the trend of political expression among young voters.

Hypothesis 4 (H4). Social media use positively influences the strength of partisanship among young voters.

\subsubsection{Outcome Orientation: Second “ $\mathrm{O}$ "}

The second orientation, also known as outcome orientation, encompasses any cognitive or behavioural outcomes of news media exposure (McLeod et al. 2002). It represents the immediate consequences of discussion, which denotes how the audience deals with media messages (Cho et al. 2009; McLeod et al. 2009). Reichert and Print (2017) advocate that news media indirectly influence political participation through other mediating variables. Cho et al. (2009) operationalized outcome orientation through political knowledge, and recommended that future researchers test some additional outcome orientations or a com- 
bination of orientations. Cho et al. (2009) also suggested exploring "especially the second $\mathrm{O}^{\prime \prime}$ to thoroughly test the communication mediation framework. Therefore, the present research responded to this suggestion and placed political efficacy, political expression, and partisanship under outcome orientation. In this way, this study tested the OSOR model thoroughly with three outcome orientations, which is novel in literature, and expanded its understanding.

\subsubsection{Response: " $\mathrm{R}$ "}

" $R$ " represents the response or outcome (McLeod et al. 2009). It is also elaborated as the possible behavioural outcome and identified as participation (Cho et al. 2009). Past literature (see de Zúñiga et al. 2012; Skoric and Poor 2013) revealed that in today's social media-oriented society, online and offline perspectives of participation need to be investigated. Therefore, in this study, online and offline political participation represented the outcome of communication behaviours.

To explore the effect of political efficacy on the political participation of youth, we proposed that political participation would be positively affected by the level of political efficacy. Previous research has observed that people with high levels of efficacy actively participate in online (Chen and Chan 2017) and offline political (Ardèvol-Abreu et al. 2019) activities. Therefore, we propose the following hypotheses:

Hypothesis 5 (H5). Political efficacy positively influences the participation of young voters in online political activities.

Hypothesis 6 (H6). Political efficacy positively influences the participation of young voters in offline political activities.

Zhu et al. (2019), in their study on the participatory behavior of young people living in Hong Kong, found a positive association between political expression (O2) on social media and political participation (R). Similarly Velasquez et al. (2021) explored the significant positive impact of political expression on the participatory behaviour of people. Keeping in view the past trend, we hypothesise that:

Hypothesis 7 (H7). Political expression positively influences the participation of young voters in online political activities.

Hypothesis 8 (H8). Political expression positively influences the participation of young voters in offline political activities.

We proposed a positive influence of partisanship on the online and offline versions of political participation. According to Wray-Lake et al. (2019), individuals with political affiliations are more likely to engage in political activities. Therefore, we propose the following hypotheses between partisanship and political participation on online and offline platforms:

Hypothesis 9 (H9). Partisan strength positively influences the participation of young voters in online political activities.

Hypothesis 10 (H10). Partisan strength positively influences the participation of young voters in offline political activities.

This study made a unique contribution by combining three different constructs under the second orientation $(\mathrm{O})$, and finding their effects on online and offline participation under the response (R). To find the justification for the use of three constructs simultaneously under the outcome $(\mathrm{O})$, we tested the mediating nature of the model. To define the 
mediating role of these orientations, we followed the segmentation approach recommended by Zhou and Pinkleton (2012) and Rungtusanatham et al. (2014).

Under the segmentation approach, the mediation of political efficacy demands the testing of the relationship between social media use and political efficacy, as well as the relationship between political efficacy and the outcome orientations of online and offline political participation. Following this, the function of political efficacy in transmitting the influence of social media use on online and offline political participation is tested. Therefore, we introduced following mediating hypotheses:

Hypothesis 11 (H11). Political efficacy among young voters positively mediates between social media use and online political participation.

Hypothesis 12 (H12). Political efficacy among young voters positively mediates between social media use and offline political participation.

The mediating role of political expression under outcome orientation demands the testing of its direct relationship with social media use, online political participation, and offline political participation. Later, the mediating role of political expression in transmitting the positive impact of social media use on online political participation and offline political participation is explored. For this purpose, we introduced following mediating hypotheses:

Hypothesis 13 (H13). Political expression among young voters positively mediates between social media use and online political participation.

Hypothesis 14 (H14). Political expression among young voters positively mediates between social media use and offline political participation.

Similarly, under the segmentation approach, the mediating role of partisanship in transferring the positive influence of social media on online and offline political participation was hypothesized as:

Hypothesis 15 (H15). Partisan strength among young voters positively mediates between social media use and online political participation.

Hypothesis 16 (H16). Partisan strength among young voters positively mediates between social media use and offline political participation.

Based on theoretical framework and past literature, this study grouped the hypotheses into ten direct-effect hypotheses and six indirect-effect hypotheses. H1 to H10 included direct effect hypotheses and H11 to H16 included indirect effect hypotheses.

Building on the prior discussion, this study introduces a conceptual framework, illustrated in Figure 1. 


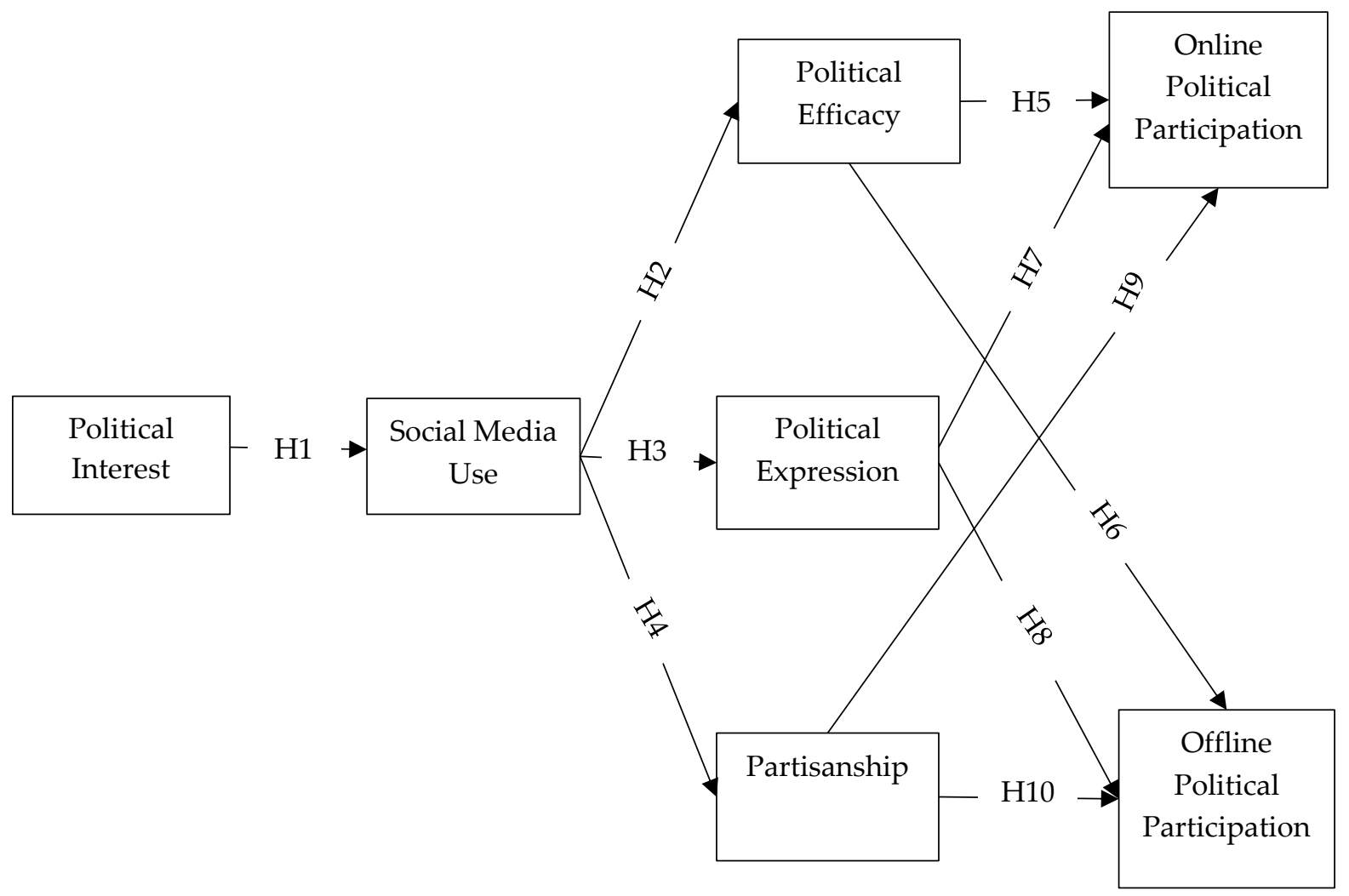

Figure 1. Social media communication mediation model.

\section{Materials and Methods}

This section describes the method utilised to collect data for this study. It also includes the demographic description of the respondents and construct measurements.

\subsection{Data Collection}

We used Google Forms for an online survey to test the proposed research model. The goal of our study was to identify the factors that influence online and offline political participation among young voters. Participants in our study, aged 18 to 29, were recruited from the Pakistani population. We utilized $G^{*}$ power analysis to calculate the sample size; this is recommended for structural equation modelling (Hair et al. 2017). According to $\mathrm{G}^{*}$ power 3.1.9.7, to obtain a medium effect size and power of 0.80 for five predictors, a minimum sample size of 92 is needed. As this study deals with a heterogenous population, we incorporated Hair et al. (2019)'s advice and increased our sample size to 385. However, we received 410 valid responses to the online survey. A sample size of 410 will yield a power of over 0.9 , which is sufficient to demonstrate satisfactory findings.

An online survey was conducted, and a multistage sampling technique was utilized to reach the target population. Unfortunately, because of the spread of COVID-19 and the strict lockdown, it was not possible to move into the field for data collection. Therefore, it was decided to incorporate snowball sampling within the multistage sampling. For the sake of data collection, the survey link was shared on different social media platforms. To ensure the recruitment of respondents from the randomly selected districts of Karachi and Toba Tek Singh, a filter question was added to the questionnaire, in which the respondents were asked about their district of residence and age. Respondents were asked to complete the online survey and share the link with other individuals in their network. The process continued until we received the required number of responses.

Although snowball sampling using an online survey is cost-effective, it has limitations of sample bias and generalizability (Sadler et al. 2010). To address these issues, Kirchherr and Charles (2018) recently recommended an increase in the sample size to minimize the 
chances of bias selection in the survey. Therefore, we increased the sample size from 92, established using $G^{*}$ power, to 410 . Previous studies have advocated comparing the study sample with national demographic statistics to avoid bias and to demonstrate whether the sample represents the true population (Baltar and Brunet 2012). The demographic statistics of this study, in Table 1, illustrated that our simple did not differ much from the demographic data of Pakistan (Pakistan Bureau of Statistics 2017). Hence, the sample bias in this study was addressed.

Table 1. Demographics.

\begin{tabular}{|c|c|c|c|}
\hline Characteristics & Description & Frequency & Percent \\
\hline \multirow{2}{*}{ Gender } & Male & 214 & 52.2 \\
\hline & Female & 196 & 47.8 \\
\hline \multirow{3}{*}{ Age } & $18-21$ & 89 & 21.7 \\
\hline & $22-25$ & 177 & 43.2 \\
\hline & $26-29$ & 144 & 35.1 \\
\hline \multirow{7}{*}{ Education Level } & Less than high school & 5 & 1.20 \\
\hline & High School & 34 & 8.30 \\
\hline & Madrassa & 6 & 1.50 \\
\hline & Bachelor's Degree & 193 & 47.10 \\
\hline & Master's Degree & 161 & 39.30 \\
\hline & PhD Degree & 4 & 1.00 \\
\hline & Prefer not to answer & 7 & 1.70 \\
\hline \multirow{7}{*}{ Profession } & Full Time & 131 & 32.00 \\
\hline & Part Time & 25 & 6.10 \\
\hline & Self Employed & 33 & 8.00 \\
\hline & Student & 150 & 36.60 \\
\hline & Disabled & 1 & 0.20 \\
\hline & Unemployed & 42 & 10.3 \\
\hline & Prefer not to answer & 28 & 6.80 \\
\hline \multirow{5}{*}{ Income (PKR) } & Below 25,000 & 86 & 21.00 \\
\hline & 25,001 to 50,000 & 132 & 32.20 \\
\hline & 50,001 to 75,000 & 70 & 17.10 \\
\hline & 75,001 to 100,000 & 46 & 11.20 \\
\hline & Above 100,000 & 76 & 18.50 \\
\hline
\end{tabular}

\subsection{Measurement}

Political interest in this study refers to personal attention towards political news and current affairs with keen observation of political activities, and seeking political information from everyday communication. Respondents were asked to rank their level of political interest on 5-point Likert scale adapted from the study of Bimber et al. (2015), Becker and Copeland (2016), and Himelboim et al. (2012).

Partisanship refers to the sense of closeness, attachment, and identification of a voter towards a particular political party. Scale items were adapted from the study of Huddy et al. (2010) and Chan (2018) to measure the partisan strength of respondents. Respondents were asked to indicate their level of association with a political party on a 5-point scale ranging from weak to extremely strong.

Social media use (SMU) refers to the purposive and frequent use of social media for the purpose of gathering political information, and to develop an understanding on political issues. Scale items were adapted from the study of Zolkepli et al. (2018) to measure the response on 5-point Likert scale ranging from "strongly disagree" to "strongly agree".

Political expression (PEX) refers to the expression of personal emotions and feelings about politics through a variety of social media tools. The scale items to measure political expression were adapted from the research performed by Gil de Zúñiga et al. (2014) and Chen and Chan (2017). The respondents were required to answer the nine statements on a scale ranging from "never" to "all the time". 
Political efficacy (PEF) refers to an individual's self-assessment of his or her ability to comprehend and engage in political activities. The present study adapted items in a political efficacy instrument from the studies of Yamamoto et al. (2017) and Pei et al. (2018), and responses were recorded on a 5-point Likert scale labelling the end points "strongly disagree" and "strongly agree".

Online political participation (ONP) refers to participation in computer-mediated political activities, i.e., online surveys, blogging, signing petitions, campaigning, joining virtual meetings and political groups etc. Based on past research by Himelboim et al. (2012), Gil de Zúñiga et al. (2014), and Chen and Chan (2017), we measured online political participation with a 5-point Likert scale ranging from "never" to "most often".

Offline political participation (OFP) refers to participation in activities such as protests, demonstrations, campaigns, voting, and meeting with officials. Offline political participation was measured by incorporating scale items from the past studies of Sayed (2012) and Gil de Zúñiga et al. (2014). A 5-point Likert scale ranging from "never" to "most often" was utilized to record the level of engagement of the respondents.

\section{Results}

\subsection{Measurement Model Assessment}

As a brief test of our theory, we utilized Partial Least Squares (PLS) path modelling. PLS is a soft modelling approach that helps to estimate the relationships among multiple variables. We employed SmartPLS 3.3.3 for this purpose. SmartPLS, developed by Ringle et al. (2005), has been utilized as a standard tool to analyse complex relationships between variables. The analysis was performed by testing the measurement model and structural model. Before assessing the measurement models for single-source data, we ran the data to find collinearity statistics by testing the variance inflation factor (VIF). The VIF values, ranging between 1.00 and 1.365, were all less than the recommended threshold of 5 (Hair et al. 2017).

For the measurement model assessment, initially, emphasis was placed on establishing the internal consistency and reliability of the constructs. Following this, the model's convergent and discriminant validity were evaluated. Here, we explored the values of the outer loadings of the items associated with the study constructs. Hereafter, we measured the composite reliability (CR) and average variance extracted (AVE). The threshold values for CR and VAE are 0.70 and 0.50, respectively (Ali et al. 2018). To retain the items with loadings between 0.50 and $0.70, \mathrm{CR}$ and AVE must surpass the aforementioned values (Hair et al. 2017; Gannon et al. 2021). The data analysis depicted that CR and AVE surpassed the threshold values; therefore, we retained all items with a loading of 0.50 or greater. The values are illustrated in Table 2.

We examined the value of discriminant validity by exploring the Fornell-Larcker criterion and Heterotrait-Monotrait (HTMT) ratio. Table 3 demonstrates that the AVE square roots of each construct are greater than the correlations with other constructs (Fornell and Larcker 1981). The HTMT ratio, an alternative criterion, was assessed as a remedy to Fornell-Larcker's lacking performance issues in discriminant validity. Table 4 shows the results report for HTMT values for all pairs of constructs, in a matrix format. It is clearly seen that the HTMT values were all below 0.90, showing that the values were conceptually more distinct from each other. Hence, the HTMT discriminant criterion is fulfilled. With this result, the discriminant validity is established, indicating that all construct are valid measures of unique concepts. 
Table 2. Measurement Model Assessment.

\begin{tabular}{|c|c|c|c|c|}
\hline Construct & Items & Loadings & CR & AVE \\
\hline \multirow{6}{*}{ Political Interest } & PI1 & 0.843 & \multirow{6}{*}{0.885} & \multirow{6}{*}{0.566} \\
\hline & PI2 & 0.773 & & \\
\hline & PI3 & 0.834 & & \\
\hline & PI4 & 0.682 & & \\
\hline & PI5 & 0.571 & & \\
\hline & PI6 & 0.775 & & \\
\hline \multirow{6}{*}{ Social Media Use } & SMU1 & 0.643 & \multirow{6}{*}{0.857} & \multirow{6}{*}{0.502} \\
\hline & SMU2 & 0.705 & & \\
\hline & SMU3 & 0.771 & & \\
\hline & SMU4 & 0.772 & & \\
\hline & SMU5 & 0.667 & & \\
\hline & SMU6 & 0.682 & & \\
\hline \multirow{6}{*}{ Political Efficacy } & PEF1 & 0.731 & \multirow{6}{*}{0.881} & \multirow{6}{*}{0.555} \\
\hline & PEF2 & 0.806 & & \\
\hline & PEF3 & 0.755 & & \\
\hline & PEF4 & 0.795 & & \\
\hline & PEF5 & 0.568 & & \\
\hline & PEF6 & 0.789 & & \\
\hline \multirow{8}{*}{$\begin{array}{l}\text { Political } \\
\text { Expression }\end{array}$} & PEX1 & 0.763 & \multirow{8}{*}{0.897} & \multirow{8}{*}{0.522} \\
\hline & PEX2 & 0.805 & & \\
\hline & PEX3 & 0.754 & & \\
\hline & PEX4 & 0.695 & & \\
\hline & PEX5 & 0.744 & & \\
\hline & PEX6 & 0.692 & & \\
\hline & PEX7 & 0.677 & & \\
\hline & PEX8 & 0.638 & & \\
\hline \multirow{7}{*}{ Partisanship } & PTS1 & 0.760 & \multirow{7}{*}{0.895} & \multirow{7}{*}{0.551} \\
\hline & PTS2 & 0.797 & & \\
\hline & PTS3 & 0.701 & & \\
\hline & PTS4 & 0.690 & & \\
\hline & PTS5 & 0.800 & & \\
\hline & PTS6 & 0.769 & & \\
\hline & PTS7 & 0.669 & & \\
\hline \multirow{8}{*}{$\begin{array}{c}\text { Online Political } \\
\text { Participation }\end{array}$} & ONP1 & 0.698 & \multirow{8}{*}{0.894} & \multirow{8}{*}{0.515} \\
\hline & ONP2 & 0.782 & & \\
\hline & ONP3 & 0.660 & & \\
\hline & ONP4 & 0.618 & & \\
\hline & ONP5 & 0.782 & & \\
\hline & ONP6 & 0.738 & & \\
\hline & ONP7 & 0.707 & & \\
\hline & ONP8 & 0.741 & & \\
\hline \multirow{6}{*}{$\begin{array}{l}\text { Offline Political } \\
\text { Participation }\end{array}$} & OFP1 & 0.836 & \multirow{6}{*}{0.898} & \multirow{6}{*}{0.596} \\
\hline & OFP2 & 0.761 & & \\
\hline & OFP3 & 0.786 & & \\
\hline & OFP4 & 0.773 & & \\
\hline & OFP5 & 0.736 & & \\
\hline & OFP6 & 0.734 & & \\
\hline
\end{tabular}


Table 3. Fornell-Larcker Criterion.

\begin{tabular}{cccccccc}
\hline Construct & PEF & OFP & ONP & PEX & PI & PTS & SMU \\
\hline PEF & 0.745 & & & & & & \\
OFP & 0.364 & 0.772 & & & & & \\
ONP & 0.394 & 0.764 & 0.718 & & & & \\
PEX & 0.426 & 0.647 & 0.672 & 0.723 & & & \\
PI & 0.588 & 0.347 & 0.394 & 0.419 & 0.752 & & \\
PTS & 0.403 & 0.493 & 0.474 & 0.440 & 0.417 & 0.742 & \\
SMU & 0.395 & 0.243 & 0.268 & 0.350 & 0.595 & 0.335 & 0.708 \\
\hline
\end{tabular}

Table 4. Discriminant Validity: HTMT.

\begin{tabular}{cccccccc}
\hline Construct & PEF & OFP & ONP & PEX & PI & PTS & SMU \\
\hline PEF & & & & & & & \\
OFP & 0.421 & & & & & & \\
ONP & 0.434 & 0.873 & & & & & \\
PEX & 0.492 & 0.737 & 0.744 & & & \\
PI & 0.696 & 0.425 & 0.449 & 0.499 & & \\
PTS & 0.471 & 0.546 & 0.512 & 0.493 & 0.499 & \\
SMU & 0.477 & 0.289 & 0.299 & 0.410 & 0.715 & 0.403 & \\
\hline
\end{tabular}

\subsection{Structural Model Assessment}

The causal relationship between the constructs was explored in a structural model. A 5000-resample bootstrapping procedure with a 5\% significance level was applied to test the one-tailed hypotheses and their significance. For the structural model assessment, the path coefficient ( $\beta$-value), the $t$-value, level of significance ( $p$-value), coefficient of determination $\left(R^{2}\right)$, and the confidence interval values were explored (Hair et al. 2017). Our findings accepted nine direct relationships and five indirect relationships. The results of the direct and indirect relationships are illustrated in Tables 5 and 6.

Table 5. Results of Structural Model (Direct Relationships).

\begin{tabular}{ccccccc}
\hline \multirow{2}{*}{ Hypothesis } & $\boldsymbol{\beta}$ Value & t Value & $\boldsymbol{p}$ Values & \multicolumn{2}{c}{ Confidence Interval } & \multirow{2}{*}{ Results } \\
\cline { 5 - 6 } & & & & $\mathbf{5 \%} \mathbf{( L L )}$ & $\mathbf{9 5 \%}$ (UL) & \\
\hline H1 & 0.595 & 16.502 & $0.000^{* *}$ & 0.538 & 0.658 & Accepted \\
H2 & 0.395 & 7.892 & $0.000^{* *}$ & 0.312 & 0.479 & Accepted \\
H3 & 0.350 & 7.621 & $0.000^{* *}$ & 0.276 & 0.426 & Accepted \\
H4 & 0.335 & 7.001 & $0.000^{* *}$ & 0.259 & 0.413 & Accepted \\
H5 & 0.079 & 1.944 & $0.026^{*}$ & 0.013 & 0.147 & Accepted \\
H6 & 0.043 & 1.026 & 0.152 & -0.024 & 0.112 & Rejected \\
H7 & 0.550 & 14.188 & $0.000^{* *}$ & 0.488 & 0.613 & Accepted \\
H8 & 0.520 & 12.937 & $0.000^{* *}$ & 0.455 & 0.586 & Accepted \\
H9 & 0.200 & 4.889 & $0.000^{* *}$ & 0.131 & 0.268 & Accepted \\
H10 & 0.247 & 6.222 & $0.000^{* *}$ & 0.182 & 0.311 & Accepted \\
\hline
\end{tabular}

Significant at $p<0.05^{*}, p<0.01^{* *}$. 
Table 6. Results of Structural Model (Indirect Relationships).

\begin{tabular}{ccccccc}
\hline \multirow{2}{*}{ Hypothesis } & \multirow{2}{*}{$\boldsymbol{\beta}$ Value } & $\boldsymbol{t}$ Value & $\boldsymbol{p}$ Value & \multicolumn{2}{c}{ Confidence Interval } & \multirow{2}{*}{ Results } \\
\cline { 5 - 6 } & & & $\mathbf{5 \%} \mathbf{( L L )}$ & $\mathbf{9 5 \%}$ (UL) & \\
\hline H11 & 0.031 & 1.813 & $0.035^{*}$ & 0.005 & 0.061 & Accepted \\
H12 & 0.017 & 0.984 & 0.162 & -0.009 & 0.046 & Rejected \\
H13 & 0.193 & 6.488 & $0.000^{* *}$ & 0.147 & 0.243 & Accepted \\
H14 & 0.182 & 6.581 & $0.000^{* *}$ & 0.139 & 0.229 & Accepted \\
H15 & 0.067 & 3.824 & $0.000^{* *}$ & 0.041 & 0.098 & Accepted \\
H16 & 0.083 & 4.783 & $0.000^{* *}$ & 0.056 & 0.113 & Accepted \\
\hline
\end{tabular}

Significant at $p<0.05^{*}, p<0.01^{* *}$.

Our results for direct relationships (see Table 5) showed a positive influence of political interest on social media use $(\beta=0.595, p<0.001)$. Similarly, social media use exhibited a positive influence on political efficacy $(\beta=0.395, p<0.001)$, political expression $(\beta=0.350$, $p<0.001)$, and partisanship $(\beta=0.335, p<0.001)$. This accepts H1, H2, H3, and H4. Political efficacy as an outcome orientation had a positive influence on online political participation $(\beta=0.079, p<0.05)$, but had no influence on offline political participation ( $\beta=0.043, p>0.05)$. This accepts H5 and rejects H6. According to our expectations, political expression as a second outcome orientation was found to be a significant factor positively influencing online $(\beta=0.550, p<0.001)$ and offline political participation $(\beta=0.520$, $p<0.001)$. Similarly, partisanship as a third outcome orientation had a significant positive influence on online $(\beta=0.200, p<0.001)$ and offline political participation $(\beta=0.247$, $p<0.001)$. Thus $\mathrm{H} 7, \mathrm{H} 8, \mathrm{H} 9$, and $\mathrm{H} 10$ are all accepted.

For mediation analysis, Baron and Kenny's (1986) approach has been extensively used, but has lately been discouraged; thereby, we employed Preacher and Hayes's (2008), the most recent method, and bootstrapped our sample distribution to investigate indirect effects. This study tested six indirect relationships to explore the mediating role of political efficacy, political expression, and partisanship in the proposed conceptual framework. The results revealed that political efficacy is a positive significant mediator between social media use and the online political activities of young voters $(\beta=0.031, p<0.05, \mathrm{CI}=0.005$, 0.061 ) but failed to mediate between social media use and the offline political activities of the same participants $(\beta=0.017, p>0.05, \mathrm{CI}=-0.009,0.046)$. This accepts $\mathrm{H} 11$ but rejects H12. Political expression was found to be a positive and significant mediator between social media use and the online $(\beta=0.193, p<0.001, \mathrm{CI}=0.147,0.243)$ and offline political activities $(\beta=0.182, p<0.001, C I=0.139,0.229)$ of young voters in Pakistan. The results also revealed partisanship as significant and positive mediator under outcome orientation between social media use and response, in the form of the online $(\beta=0.067, p<0.001$, $\mathrm{CI}=0.041,0.098)$ and offline $(\beta=0.083, p<0.001, \mathrm{CI}=0.056,0.113)$ political activities of young voters. Hence H13, H14, H15, and H16 are also accepted.

The findings illustrate that all variables under the outcome orientations overwhelmingly mediated the relationship between stimulus and response in the OSOR communication mediation model. The coefficient of determination $\left(R^{2}\right)$ values of online political participation $\left(R^{2}=0.495\right)$ and offline political participation $\left(R^{2}=0.474\right)$ described a moderate predictive accuracy of the model. Taken together, our exogenous variables explained $49.5 \%$ and $47.4 \%$ of the variance in online political participation and offline political participation, respectively, and this variance is satisfactory (Hair et al. 2017). The structural model assessment is explained in Figure 2. 


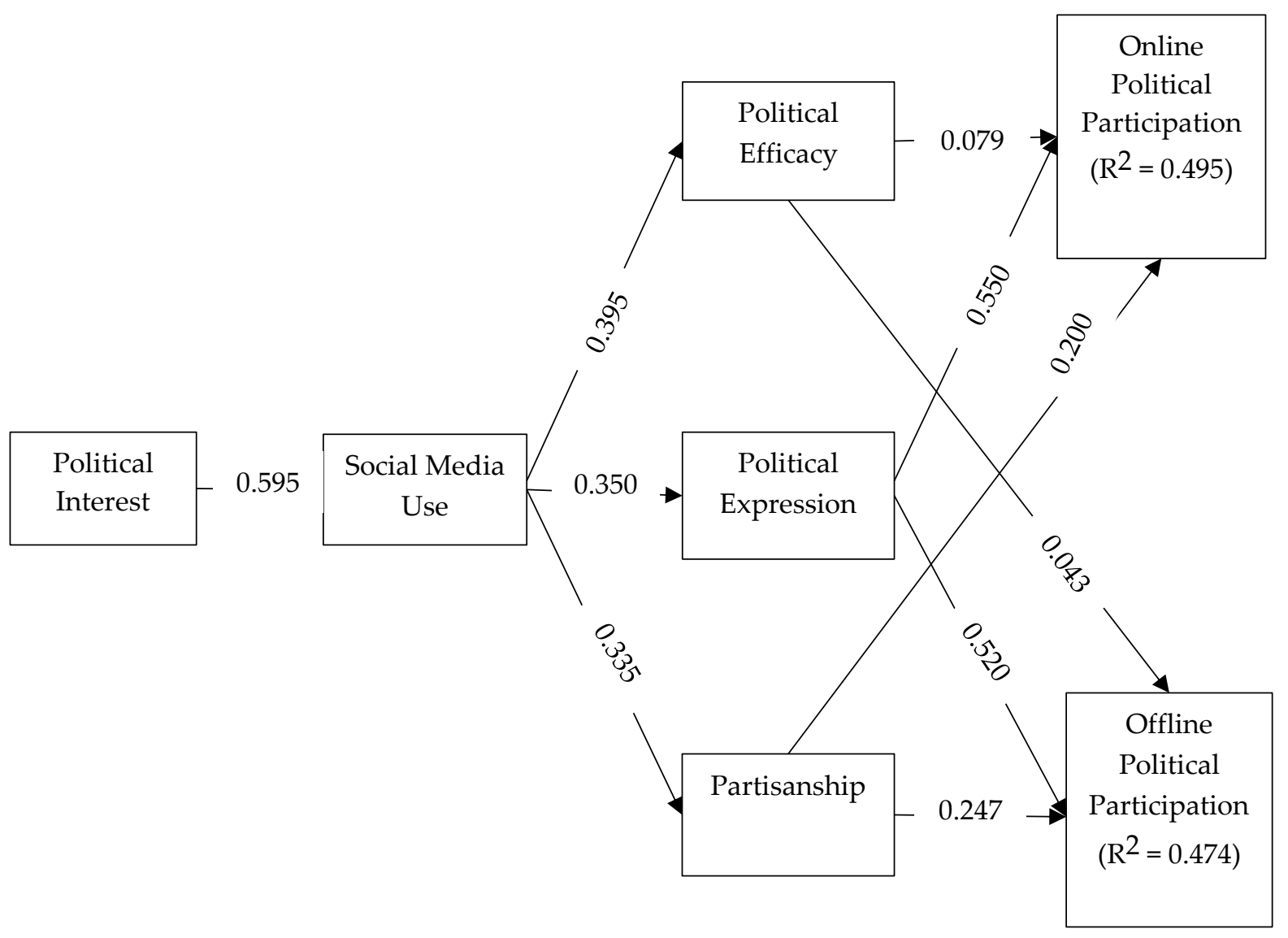

Figure 2. Structural model for social media communication mediation.

\section{Discussion}

We developed a social media communication mediation model using the OSOR model and previous literature. We specifically examined the impact of political interest among young voters on their social media use, and how political efficacy, political expressiveness, and partisanship, as mediators, transfer the positive impact of social media on online and offline political participation. Our findings revealed that the participants with political interests are more frequent users of social media in Pakistan. Consequently, in Pakistan, the higher the level of antecedent orientation of political interest, the higher the social media use. This study challenged the general perception of scholars that political interest is an outcome of social media use, and found political interest as a predictor of social media use. This finding coincides with the study of Lecheler and Vreese (2017). It also approves Tian (2011)'s recommendation by successfully treating the psychological disposition, such as political interest, as an antecedent orientation in communication mediation models that affect media use patterns.

Our results clearly establish that pursuing social media for political information eventually encourages citizens to make a contribution in the ongoing political conversations on these platforms or start a new discussion to express their viewpoint. The available political information on social media expedites the process of analytical reasoning. The development of relevant reasons encourages social media users to express themselves politically on social media sites. Evidence from Bode et al. (2014) and Artime (2016)'s research also manifests that social media users express themselves by commenting on political posts, writing blogs, posts about elections and political leaders, criticizing policies of rulers, interacting with the political accounts, and frequent sharing of political content such as photos, videos, and audios. Thus, our results clearly explained that young voters in Pakistan who use social media are expressive in sharing and conveying their political 
observations. This expressive behavior further led them to actively contribute to online and offline political activities.

As expected, our results showed that consistent interaction with political content develops a sense of efficacy among young voters who feel that they are informed and competent enough to understand the political issue. This competence led them to indulge in political activities on social media forums or similar activities in the offline environment. Although political participation is not substantial to determine society as a truly democratic society, many additional political and psychological variables need to be studied in Pakistan. However, this situation is hopeful for democratic strength in the country (Batool et al. 2020). Moeller et al. (2014) also identified political efficacy as a personality trait that influenced citizens' participation in political activities. Voting behaviour is the most effective and result oriented form of political participation, and an outcome of the political process is explored as a significant outcome of political efficacy.

Our study demonstrated that, in a modern democracy, the segregation of political platforms into online and offline contexts did not change the historic positive association between political participation and political efficacy. Political efficacy has a strong association with the online political participation of citizens. It has been determined, in American culture, that an increase in political efficacy boosts the level of online political participation (Mazzurco 2019). Our research also found that political efficacy has a substantial effect on young voters' engagement in online political activities in Pakistan. Reichert (2016), in a study, aimed to develop a consensus on the impact of the informational use of social media on political participation, and proposed political efficacy as a mechanism that converts social media use for information into conventional political activities. Contrary to this, our findings negate the outcome of Reichert's (2016) research. Our research proved that political efficacy among young voters has no link with conventional political activities in an offline environment. This insignificant relationship shows that political efficacy is not politically consequential in determining offline political actions, in an unstable democratic environment such as Pakistan.

Findings from past literature identified partisanship as a key behavior to predict the participation of citizens in political activities, and in determining the democratic strength of the society (Bartels 2000). Scholars (see Giglietto et al. 2019; Shahzad and Omar 2021) demonstrated that people with partisan orientation are motivated to participate in political activities on social media for the purpose of political support of one's political party, and that this participation later shapes offline political behaviors. Consistent with this perspective, we also found that the partisan strength of young voters positively influenced their participation in online and offline political activities. Consequently, the greater the degree of partisan identity, the more the sense of consciousness will be towards maintaining the positive status of one's political party. This consciousness towards partisan identity enhances the engagement of young voters in online and offline political activities in Pakistan. Although the influence of partisan strength on different political behaviors has been studied in the past, its mediating role in the communication mediation model as an outcome orientation and in the context of Pakistan was novel in the literature; this demonstrates the contribution of our study.

Our research also contributes to the advancement in the theoretical testing of the communication mediation approach, by incorporating Cho et al. (2009)'s recommendation to use a combination of outcome orientations. Enlisting political efficacy, political expression, and partisanship as three outcome orientations and justifying their mediating role is also a significant contribution of our research. The adoption of the segmentation approach to test mediation effect is another unique step that differentiate this study from the past literature. Normally, previous literature rarely discusses the method for development of mediating relationship while testing mediation path in communication mediation models. They usually follow the established links of communication mediation process. We made a unique contribution, specifically in the communication mediation literature, by utilizing the segmentation method of testing the mediation effect in the OSOR model. 
There is a perception that young, educated people, especially female, are not interested in politics in Pakistan. Multiple reasons are presented for this deactivation in politics. In contrast, the findings of this study negated all of these. Most of the participants in this research has graduated from universities; more than $47 \%$ were female; and their political interests guided them to political participation via social media use. Therefore, we suggest a value-adding step in policy making to encourage social media and political forums, for citizens to express as much as they can. This will eliminate the perception of political uncertainty from youth and, consequently, will motivate them to take part in political activities. However, unfortunately, policy making bodies in the government of Pakistan are working in the opposite direction. In light of this discussion, this study suggests that the current government in Pakistan reconsider the decision to promulgate the Pakistan Media Regulatory Authority Ordinance 2021, which is especially designed to curb freedom of expression on social media platforms. This ordinance is already rejected by the journalist representative bodies and is largely discussed as draconian law among media practitioners (Hussain 2021). If the ordinance is promulgated, it will demotivate the youth to express their opinions, which will ultimately result in decline in participation.

We also suggest that media bodies should employ some self-regulations before sharing news. After the emergence of social media, it has become especially easy and affordable to launch a YouTube channel. There is a trend among vloggers in Pakistan of sharing baseless, sensational news and conspiracy theories. Here, the role of journalist unions and media bodies is very important, to at least convince journalists who have YouTube channels to avoid and discourage such practice; in this way, people can rely on social media content, and at the time of elections or other political activities, they might be easily convinced to participate in real-life politics.

\section{Limitations and Recommendations}

Our study has some limitations. Firstly, we faced hurdles in data collection because of the COVID-19 pandemic. Initially, we aimed to collect data by utilizing a multistage cluster sampling technique that required door-to-door physical access. The movement was not possible due health risks and the strict lock down in Pakistan. To overcome this hurdle, the multistage sampling technique was used with the incorporation of snowball sampling. Secondly, at the time that data collection started, heavy monsoon rains flooded the Karachi city. Additionally, there was a heavy power breakdown, and electricity was available only for a few hours, and sometimes every couple of days. It also affected people's internet access. Due to all of these calamities, it took several extra months to collect data from Karachi, compared with Toba Tek Singh. Thirdly, our study is cross sectional; the findings could differ if data were to be collected in a longitudinal research design. The aforementioned limitations could be objects of improvement in future research.

Research on the role of social media for political participation is, relatively, not a new trend; however, still there is a lot of scope for the future researchers to further investigate the concept of social media use for political participation. Most of the published space is occupied by established democracies. Therefore, we recommend diverting focus onto less-established democracies and further concentrating on the comparison between developed and developing democracies, according to the democracy index (Economist 2020). This will enhance the scope of the communication mediation approach in the specific category of democracy. In a theoretical context, this study recommends incorporating partisanship as an antecedent orientation, and testing its role as a moderator of social media use (i.e., stimuli as proposed by McLeod et al. (2009)), as well as testing its direct influence on response by combining social identity theory (SIT) with a communication mediation model. Future scholars might use these suggestions to provide more robust theoretical and practical outcomes. 


\section{Conclusions}

This research contributes to political communication and the social media domain by modeling the political participation of young voters in Pakistan through social media communication effects. The study explores social media use and underlying behavioral characteristics that influence people's involvement in political activities. Knowledge about the process of interest-oriented social media use in political participation was advanced by applying the OSOR model. The path model connected the variables of political interest, social media use, political efficacy, political expression, partisanship, online political participation, and offline political participation. The theorized path model, containing mediation paths, was tested for measurement and structural model using SmartPLS 3.3.3. Most of the relationships in the path model were found to be significant, which provides support for the model.

Overall, the findings depict a supportive view of social media's positive effect on the political participation of young voters in Pakistan. Our study suggests that the influential political role of social media platforms in developing democracies, such as Pakistan, is similar to the developed and mature democracy of the United Kingdom as explained by Brändle et al. (2022). In our model, though all of the effects of social media on political participation were indirect, these indirect effects proved that social media use is as effective indirectly as it is directly in enhancing participation in political activities. The findings can be useful in fixing the problem of decline in political participation among youth. The implications of this study are also fruitful for the countries where there is a weak democracy, or where democracy is still trying to gain strength.

Author Contributions: Conceptualization, R.T. and I.A.Z.; Data curation, I.A.Z.; Formal analysis, R.T.; Investigation, R.T.; Methodology, R.T.; Project administration, R.T.; Resources, M.A.; Software, R.T.; Supervision, I.A.Z.; Validation, I.A.Z. and M.A.; Visualization, M.A.; Writing—original draft, R.T.; Writing-review \& editing, I.A.Z. All authors have read and agreed to the published version of the manuscript.

Funding: This research was funded by Universiti Sains Malaysia under the grant RUI/1001/PCOMM/ 8016072 .

Institutional Review Board Statement: This research was approved by the human resource ethics committee of Univerisiti Sains Malaysia under study protocol code USM/JEPeM/19100624.

Informed Consent Statement: Informed consent was obtained from all subjects involved in this study.

Data Availability Statement: The data presented in this study are available on request from the corresponding author. The data are not publicly available in order to protect the privacy and confidentiality of study participants.

Conflicts of Interest: The authors declare no conflict of interest.

\section{References}

Ahmad, Khalil, and Karim Sajjad Sheikh. 2013. Social Media and Youth Participatory Politics: A Study of University Students. South Asian Studies 28: 353-60.

Ahmad, Taufiq, Aima Alvi, and Muhammad Ittefaq. 2019. The Use of Social Media on Political Participation Among University Students: An Analysis of Survey Results from Rural Pakistan. SAGE Open 9: 2158244019864484. [CrossRef]

Ahmed, Saifuddin, and Marko M. Skoric. 2014. My name is Khan: The use of twitter in the campaign for 2013 Pakistan general election. Paper presented at 47th Hawaii International Conference on System Sciences, Waikoloa, HI, USA, January 6-9; pp. $2242-51$. [CrossRef]

Ali, Faizan, Seyyed Mostafa Rasoolimanesh, Marko Sarstedt, Christian M. Ringle, and Kisang Ryu. 2018. An assessment of the use of partial least squares structural equation modeling (PLS-SEM) in hospitality research. International Journal of Contemporary Hospitality Management 30: 514-38. [CrossRef]

Ali, Zafar, Mirza Jan, and Ashraf Iqbal. 2013. Social media implication on politics of Pakistan: Measuring the impact of Facebook. Journal of Social Sciences 5: 123-37.

Almeida, Fernando. 2017. Concept and Dimensions of Web 4. 0. International Journal of Computer E Technology 16: 7040-46. [CrossRef]

Alphapro. 2018. Pakistan Social Media Stats 2018. Available online: http://alphapro.pk/pakistan-social-media-stats-2018/ (accessed on 5 February 2019). 
Ardèvol-Abreu, Alberto, Trevor Diehl, and Homero Gil de Zúñiga. 2019. Antecedents of internal political efficacy incidental news exposure online and the mediating role of political discussion. Politics 39: 82-100. [CrossRef]

Artime, Michael. 2016. Angry and Alone: Demographic Characteristics of Those Who Post to Online Comment Sections. Social Sciences 5: 68. [CrossRef]

Bakker, Tom P., and Claes H. de Vreese. 2011. Good News for the Future? Young People, Internet Use, and Political Participation. Communication Research 38: 451-70. [CrossRef]

Baltar, Fabiola, and Ignasi Brunet. 2012. Social research 2.0: Virtual snowball sampling method using Facebook. Internet Research 22: 57-74. [CrossRef]

Baron, Reuben M., and David A. Kenny. 1986. The moderator-mediator variable distinction in social psychological research: Conceptual, strategic, and statistical considerations. Journal of Personality and Social Psychology 51: 1173-82. [CrossRef]

Bartels, Larry M. 2000. Partisanship and Voting Behavior, 1952-1996. American Journal of Political Science 44: 35-50. [CrossRef]

Batool, Sumera, Zaeem Yasin, and Aaima Batool. 2020. Role of Social Media in Democratization in Pakistan: An Analysis of Political Awareness, Efficacy and Participation in Youth. International Review of Social Sciences 8: 144-61.

Baumgartner, Jody C., and Jonathan S. Morris. 2010. MyFaceTube Politics: Social Networking Web Sites and Political Engagement of Young Adults. Social Science Computer Review 28: 24-44. [CrossRef]

Becker, Amy B., and Lauren Copeland. 2016. Networked publics: How connective social media use facilitates political consumerism among LGBT Americans. Journal of Information Technology \& Politics 13: 22-36.

Bimber, Bruce, Marta Cantijoch Cunill, Lauren Copeland, and Rachel Gibson. 2015. Digital Media and Political Participation: The Moderating Role of Political Interest Across Acts and Over Time. Social Science Computer Review 33: 21-42. [CrossRef]

Bode, Leticia, Emily K. Vraga, Porismita Borah, and Dhavan V. Shah. 2014. A new space for political behavior: Political social networking and its democratic consequences. Journal of Computer-Mediated Communication 19: 414-29. [CrossRef]

Boyd, Danah. 2008. Can social network sites enable political action? International Journal of Media and Cultural Politics 4: 241-63. [CrossRef]

Brändle, Verena K., Charlotte Galpin, and Hans-Jörg Trenz. 2022. Brexit as 'politics of division': Social media campaigning after the referendum. Social Movement Studies 21: 234-53. [CrossRef]

Campbell, Timothy. 2020. The Role of Political Skepticism, Reactance, and Partisan Bias in Shaping Attitudes on Climate Change in the United States. Vancouver: University of British Columbia.

Cervi, Laura, and Carles Marín-Lladó. 2021. What are political parties doing on TikTok? The Spanish case. Profesional de La Información 30: e300403. [CrossRef]

Chan, Michael. 2018. Partisan Strength and Social Media Use Among Voters During the 2016 Hong Kong Legislative Council Election: Examining the Roles of Ambivalence and Disagreement. Journalism \& Mass Communication Quarterly 95: 343-62. [CrossRef]

Chen, Zhuo, and Michael Chan. 2017. Motivations for Social Media Use and Impact on Political Participation in China: A Cognitive and Communication Mediation Approach. Cyberpsychology, Behavior, and Social Networking 20: 83-90. [CrossRef] [PubMed]

Cho, Jaeho, Dhavan V. Shah, Jack M. McLeod, Douglas M. McLeod, Rosanne M. Scholl, and Melissa R. Gotlieb. 2009. Campaigns, Reflection, and Deliberation: Advancing an O-S-R-O-R Model of Communication Effects. Communication Theory 19: 66-88. [CrossRef]

de Zúñiga, Homero, Nakwon Jung, and Sebastián Valenzuela. 2012. Social Media Use for News and Individuals' Social Capital, Civic Engagement and Political Participation. Journal of Computer-Mediated Communication 17: 319-36. [CrossRef]

Economist. 2020. Democracy Index 2020: In Sickness and in Health. Available online: https://pages.eiu.com/rs/753-RIQ-43 8/images / democracy-index-2020.pdf?mkt_tok=NzUzLVJJUS00MzgAAAF9EksavbXymZwYyYdvOTJJOBr6Yjd7xwvn9oa7 bmVlpB-eASIfYhJjyB_r-h8_wCBDQWsqUWC1kBba0UIblhDzjVR0tILmt99udP173auNLNQo7g (accessed on 10 July 2021).

Election Commission of Pakistan. 2013. National Assembly Turnout Comparison 2013 \& 2008. Available online: https://www.ecp.gov. pk/Documents/Downloads/GeneralElection2013/Statistics/NationalAssemblyTurnoutComparison2008\&2013.jpg (accessed on 15 March 2020).

Election Commission of Pakistan. 2018. Assembly Wise Voters Turnout. Available online: https://www.ecp.gov.pk/frmstats.aspx (accessed on 19 March 2020).

Fakih, Ali, Nathir Haimoun, and Mohamad Kassem. 2020. Youth Unemployment, Gender and Institutions During Transition: Evidence from the Arab Spring. Social Indicators Research 150: 311-36. [CrossRef]

Foa, Roberto Stefan, Andrew Klassen, Dennis Wenger, Alex Rand, and Michael Slade. 2020. Youth and Satisfaction with Democracy. Cambridge: Bennett Institute for Public Policy.

Fornell, Claes, and David F. Larcker. 1981. Evaluating Structural Equation Models with Unobservable Variables and Measurement Error. Journal of Marketing Research 18: 39-50. [CrossRef]

Galandini, Silvia, and Edward Fieldhouse. 2019. Discussants that mobilise: Ethnicity, political discussion networks and voter turnout in Britain. Electoral Studies 57: 163-73. [CrossRef]

Gallup Pakistan. 2018. Opinion Poll from Gallup Pakistan. Gallup Pakistan. Available online: https://gallup.com.pk/48-internet-usersin-pakistan-claim-to-use-social-networking-sites-to-access-news-at-least-once-a-day/ (accessed on 10 August 2021).

Gannon, Martin, Sayyed Mostafa Rasoolimanesh, and Babak Taheri. 2021. Assessing the Mediating Role of Residents' Perceptions toward Tourism Development. Journal of Travel Research 60: 149-71. [CrossRef] 
Giglietto, Fabio, Augusto Valeriani, Nicola Righetti, and Giada Marino. 2019. Diverging patterns of interaction around news on social media: Insularity and partisanship during the 2018 Italian election campaign. Information, Communication E Society 22: 1610-29. [CrossRef]

Gil de Zúñiga, Homero, Logan Molyneux, and Pei Zheng. 2014. Social media, political expression, and political participation: Panel analysis of lagged and concurrent relationships. Journal of Communication 64: 612-34. [CrossRef]

Grasso, Maria, and Marco Giugni. 2022. Intra-generational inequalities in young people's political participation in Europe: The impact of social class on youth political engagement. Politics 42: 13-38. [CrossRef]

Grechyna, Daryna. 2020. Technological Progress and Political Disengagement. Available online: https://ssrn.com/abstract=3570643 (accessed on 2 February 2021).

Guven, Ada. 2020. Democracy and prevention of corruption in the European legislation. European Journal of Interdisciplinary Studies Articles 6: 52-65. [CrossRef]

Hair, Joseph F., Christian M. Ringle, Siegfried P. Gudergan, Andreas Fischer, Christian Nitzl, and Con Menictas. 2019. Partial least squares structural equation modeling-based discrete choice modeling: An illustration in modeling retailer choice. Business Research 12: 115-42. [CrossRef]

Hair, Joseph F., G. Tomas M. Hult, Christian M. Ringle, Marko Sarstedt, and Kai Oliver Thiele. 2017. Mirror, mirror on the wall: A comparative evaluation of composite-based structural equation modeling methods. Journal of the Academy of Marketing Science 45: 616-32. [CrossRef]

Halpern, Daniel, and Jennifer Gibbs. 2013. Social media as a catalyst for online deliberation? Exploring the affordances of Facebook and YouTube for political expression. Computers in Human Behavior 29: 1159-68. [CrossRef]

Halpern, Daniel, Sebastián Valenzuela, and James E. Katz. 2017. We Face, I Tweet: How Different Social Media Influence Political Participation through Collective and Internal Efficacy. Journal of Computer-Mediated Communication 22: 320-36. [CrossRef]

Himelboim, Itai, Ruthann Weaver Lariscy, Spencer F. Tinkham, and Kaye D. Sweetser. 2012. Social Media and Online Political Communication: The Role of Interpersonal Informational Trust and Openness. Journal of Broadcasting E Electronic Media 56: 92-115. [CrossRef]

Hoffman, Lindsay H., and Tiffany L. Thomson. 2009. The effect of television viewing on adolescents' civic participation: Political efficacy as a mediating mechanism. Journal of Broadcasting and Electronic Media 53: 3-21. [CrossRef]

Holt, Kridtoffer, Adam Shehata, Jesper Strömbäck, and Elisabet Ljungberg. 2013. Age and the effects of news media attention and social media use on political interest and participation: Do social media function as leveller? European Journal of Communication 28: 19-34. [CrossRef]

Huddy, Leonie, Lilliana Mason, and Lene Aaroe. 2010. Measuring Partisanship as a Social Identity, Predicting Political Activism. Paper presented at Annual Meeting of the International Society for Political Psychology, San Francisco, CA, USA, July 7-10.

Hussain, Sayed Talat. 2021. Imran Govt Attempts to Create Another Black Law. STH. Available online: https:/ / www.youtube.com/watch? $\mathrm{v}=$ ZBQzoEZptSU (accessed on 3 June 2021).

Hwang, Hyesun. 2020. Does Social Media Close the Political Efficacy Gap to Participate in Politics? In HCI International 2020-Posters. Edited by Constantine Stephanidis and Margherita Antona. Copenhagen: Springer International Publishing, pp. 169-76.

Ida, Rachmah, Muhammad Saud, and Musta'in Mashud. 2020. An empirical analysis of social media usage, political learning and participation among youth: A comparative study of Indonesia and Pakistan. Quality and Quantity 54: 1285-97. [CrossRef]

Iftikhar, Ifra, Irem Sultana, and Malik Adnan. 2021. Political Discussions on Social Media in Pakistan and Obstinate Partisanship. Global Political Review VI: 121-31. [CrossRef]

Joseph, Sarah. 2011. Social Media, Human Rights and Political Change. Boston College International and Comparative Law Review 35: 35-145. [CrossRef]

Khanzode, Chhaya A., and Ravindra D. Sarode. 2016. Evolution of the world wide web: From web 1.0 to 6.0. International Journal of Digital Library Services 6: 1-11.

Kim, Bumsoo, and Jennifer Hoewe. 2020. Developing contemporary factors of political participation. Social Science Journal. [CrossRef]

Kirchherr, Julian, and Katrina Charles. 2018. Enhancing the sample diversity of snowball samples: Recommendations from a research project on anti-dam movements in Southeast Asia. PLoS ONE 13: e0201710. [CrossRef]

Kushin, Matthew James, and Masahiro Yamamoto. 2010. Did social media really matter? college students' use of online media and political decision making in the 2008 election. Mass Communication and Society 13: 608-30. [CrossRef]

Lane, Daniel S. 2020. In Search of the Expressive Citizen: Citizenship Norms and Youth Political Expression on Social Media. Public Opinion Quarterly 84: 257-83. [CrossRef]

Langa, Malose. 2017. Researching the \#FeesMustFall movement. In \#Hashtag an Analysis of the \#FeesMustFall Movement at South African Universities. Johannesburg: Centre for the Study of Violence and Reconciliation (CSVR), pp. 132-48.

Lecheler, Sophie, and Claes H. de Vreese. 2017. News Media, Knowledge, and Political Interest: Evidence of a Dual Role from a Field Experiment. Journal of Communication 67: 545-64. [CrossRef]

Lee, Nam-Jin. 2017. Communication Mediation Model. In The International Encyclopedia of Media Effects. Atlanta: American Cancer Society, pp. 1-9. [CrossRef]

Lee, Sangwon, and Michael Xenos. 2019. Social distraction? Social media use and political knowledge in two U.S. Presidential elections. Computers in Human Behavior 90: 18-25. [CrossRef]

Lipschultz, Jeremy Harris. 2015. Social Media Communication: Concepts, Practices, Data, Law and Ethics, 1st ed. London: Routledge. 
Lu, Yanqin, and Jae Kook Lee. 2021. Determinants of cross-cutting discussion on Facebook: Political interest, news consumption, and strong-tie heterogeneity. New Media E Society 23: 175-92. [CrossRef]

Mahmood, Qaisar Khalid, Sara Rizvi Jafree, and Malik Muhammad Sohail. 2020. Pakistani Youth and Social Media Addiction: The Validation of Bergen Facebook Addiction Scale (BFAS). International Journal of Mental Health and Addiction 20: 581-94. [CrossRef]

Mangi, Shah Nawaz, Naimatullah Shah, and Ali Bahadur Soomro. 2019. A scientific approach to measure public political participation in Pakistan. Asian Journal of Political Science 1: 1-20. [CrossRef]

Mazzurco, S. 2019. E-Citizenship: Trust in Government, Political Efficacy, and Political Participation in the Internet Era. Electronic Media E Politics 1: 119-35.

McLeod, Dogles M., Gerald M. Kosicki, and Jack M. McLeod. 2002. Resurveying the Boundaries of Political Communications Effects. In Media Effects Advances in Theory and Research. Edited by Jennings Bryant and Dolf Zillmann. London: Routledge, pp. $215-67$.

McLeod, Dougles M., Gerald M. Kosicki, and Jack M. McLeod. 2009. Political Communication Effects. In Media Effects: Advances in Theory E Research, 3rd ed. Edited by J. Bryant and Mary B. Oliver. London: Routledge, pp. 228-51.

Michaelsen, Marcus. 2011. New media vs. old politics: The internet, social media, and democratisation in Pakistan. In Fesmedia Asia. Berlin: Friedrich-Ebert-Stiftung.

Min, Seong-Jae. 2010. From the digital divide to the democratic divide: Internet skills, political interest, and the second-level digital divide in political internet use. Journal of Information Technology \& Politics 7: 22-35. [CrossRef]

Moeller, Judith, Claes de Vreese, Frank Esser, and Ruth Kunz. 2014. Pathway to Political Participation: The Influence of Online and Offline News Media on Internal Efficacy and Turnout of First-Time Voters. American Behavioral Scientist 58: 689-700. [CrossRef]

Musarurwa, Hailary Jephat. 2016. The Rise of Youth Activism and Non-violent Action in Addressing Zimbabwe's Crisis. Conflict Trends 2016: 50-56. [CrossRef]

Mustapha, Lambe Kayode, and Bahiyah Omar. 2020. Do social media matter? Examining social media use and youths' political participation during the 2019 Nigerian general elections. The Round Table 109: 441-57. [CrossRef]

Ohme, Jakob. 2021. Algorithmic social media use and its relationship to attitude reinforcement and issue-specific political participationThe case of the 2015 European immigration movements. Journal of Information Technology \& Politics 18: 36-54. [CrossRef]

Pakistan Bureau of Statistics. 2017. Population Census 2017. Available online: http://www.pbs.gov.pk/content/population-census (accessed on 11 March 2021).

Patrut, Bogdan, and Monica Patrut. 2014. Social Media in Politics. Edited by Bogdan Pătrut and Monica Pătrut. Cham: Springer. [CrossRef]

Pei, Zhijun, Yingchun Pan, and Martin Skitmore. 2018. Political Efficacy, Social Network and Involvement in Public Deliberation in Rural China. Social Indicators Research 139: 453-71. [CrossRef]

Preacher, Kristopher J., and Andrew F. Hayes. 2008. Assessing mediation in communication research. In The Sage Sourcebook of Advanced Data Analysis Methods for Communication Research. Thousand Oaks: SAGE Publications, Inc., pp. 13-54.

Reichert, Frank. 2016. How Internal Political Efficacy Translates Political Knowledge into Political Participation: Evidence from Germany. Europe's Journal of Psychology 12: 221-41. [CrossRef]

Reichert, Frank, and Murray Print. 2017. Mediated and moderated effects of political communication on civic participation. Information Communication and Society 20: 1162-84. [CrossRef]

Ringle, Christian M., Sven Wende, and Aihwsd Will. 2005. SmartPLS 2.0 (Beta). Available online: https://www.smartpls.com/ (accessed on 10 January 2021).

Rungtusanatham, M., J. W. Miller, and K. K. Boyer. 2014. Theorizing, testing, and concluding for mediation in SCM research: Tutorial and procedural recommendations. Journal of Operations Management 32: 99-113. [CrossRef]

Sadler, Georgia Robins, Hau-Chen Lee, Rod Seung-Hwan Lim, and Judith Fullerton. 2010. Research Article: Recruitment of hard-toreach population subgroups via adaptations of the snowball sampling strategy. Nursing $\mathcal{E}$ Health Sciences 12: 369-74. [CrossRef]

Sayed, Nermeen. 2012. Towards the Egyptian Revolution: Activists' perceptions of social media for mobilization. Journal of Arab E Muslim Media Research 4: 273-98. [CrossRef]

Schmalzer, Sigrid. 2015. 6. Youth and the "Great Revolutionary Movement" of Scientific Experiment in 1960s-1970s Rural China. In Maoism at the Grassroots: Everyday Life in China's Era of High Socialism. Edited by Jeremy Brown and Matthew D. Johnson. Cambridge: Harvard University Press, pp. 154-78. [CrossRef]

Shahzad, Sobia, and Bahiyah Omar. 2021. Social network matters: The influence of online social capital on youth political participation in Pakistan. Journal of Information Technology E Politics 18: 430-42. [CrossRef]

Skoric, M. M., and N. Poor. 2013. Youth Engagement in Singapore: The Interplay of Social and Traditional Media. Journal of Broadcasting and Electronic Media 57: 187-204. [CrossRef]

Statista. 2018. Number of Internet Users in the Asia Pacific Region as of January 2018, by Country (in Millions). Available online: https: / www.statista.com/statistics/265153/number-of-internet-users-in-the-asia-pacific-region/ (accessed on 2 February 2021).

Statista. 2021. Most Popular Social Networks Worldwide as of January 2021, Ranked by Number of Active Users. Statista.Com. Available online: https://www.statista.com/statistics/272014/global-social-networks-ranked-by-number-of-users / (accessed on 6 September 2021).

Széll, György. 2018. Democracy and participation in the twenty-first century. International Review of Sociology 28: 209-15. [CrossRef] 
Tharoor, Ishaan. 2018. Pakistan's military has its fingerprints all over the elections. The Washington Post. Available online: https:/ / www.washingtonpost.com/news/worldviews/wp/2018/07/25/pakistans-military-has-its-fingerprints-all-over-theelections/?utm_term=.8ef33ab30861 (accessed on 15 March 2021).

Thompson, Nik, Xuequn Wang, and Pratiq Daya. 2020. Determinants of News Sharing Behavior on Social Media. Journal of Computer Information Systems 60: 593-601. [CrossRef]

Tian, Yan. 2011. Communication behaviors as mediators: Examining links between political orientation, political communication, and political participation. Communication Quarterly 59: 380-94. [CrossRef]

Velasquez, Alcides, and Harnando Rojas. 2017. Political Expression on Social Media: The Role of Communication Competence and Expected Outcomes. Social Media + Society 3: 1-13. [CrossRef]

Velasquez, Alcides, Andrea M. Quenette, and Hernando Rojas. 2021. WhatsApp Political Expression and Political Participation: The Role of Ethnic Minorities' Group Solidarity and Political Talk Ethnic Heterogeneity. International Journal of Communication 15: 2743-64.

Wray-Lake, Laura, Erin H. Arruda, and David A. Hopkins. 2019. The Party Goes On: U.S. Young Adults' Partisanship and Political Engagement Across Age and Historical Time. American Politics Research 47: 1358-75. [CrossRef]

Yamamoto, Masahiro, Matthew James Kushin, and Frncis Dalisay. 2017. Social Media and Political Disengagement Among Young Adults: A Moderated Mediation Model of Cynicism, Efficacy, and Social Media Use on Apathy. Mass Communication and Society 20: 149-68. [CrossRef]

Yamamoto, Masahiro, Seungahn Nah, and So Young Bae. 2020. Social media prosumption and online political participation: An examination of online communication processes. New Media and Society 22: 1885-902. [CrossRef]

Zhou, Yushu, and Bruce E. Pinkleton. 2012. Modeling the Effects of Political Information Source Use and Online Expression on Young Adults' Political Efficacy. Mass Communication and Society 15: 813-30. [CrossRef]

Zhu, Alex Yue Feng, Alex Lih Shing Chan, and Kee Lee Chou. 2019. Creative social media use and political participation in young people: The moderation and mediation role of online political expression. Journal of Adolescence 77: 108-17. [CrossRef]

Zolkepli, Izzal Asnira, Yusniza Kamarulzaman, and Philip J. Kitchen. 2018. Uncovering Psychological Gratifications Affecting Social Media Utilization: A Multiblock Hierarchical Analysis. Journal of Marketing Theory and Practice 26: 412-30. [CrossRef] 